○特集 $\mid$ フィルム・シート技術の最新技術

\title{
Solid-in-Oil $\left(\mathbf{S} / \mathbf{O}^{\circledR}\right)$ 製剤技術を利用したオイルゲルシート
}

\author{
船津麻美 1$) *$ ・田原義朗 2) ・ 山中桜子 3) ・後藤雅宏 $2,3,4)$ \\ 1）リバテープ製薬株式会社％ 861-0136 熊本県熊本市植木町岩野 45 \\ 2) 九州大学 大学院工学研究院 応用化学部門 $\overline{7} 819-0395$ 福岡県福岡市西区元岡 744 \\ 3） SO ファーマ株式会社％ 650-0047 兵庫県神戸市中央区港島南町 1-5-2 \\ 4）九州大学 未来化学創造センター ～819-0395 福岡県福岡市西区元岡 744
}

\section{Oil Gel Sheets Utilizing Solid-in-Oil Technique}

\author{
Asami Funatsu $^{1)}$, Yoshiro Tahara ${ }^{2)}$, Sakurako Yamanaka $^{3)}$, and Masahiro Goto ${ }^{2,3,4)}$ \\ 1) Libatape Corporation, 45 Iwano-Uekimachi, Kumamoto 861-0136, Japan \\ 2) Department of Applied Chemistry, Graduate School of Engineering, Kyusyu University,744 \\ Moto-oka, Fukuoka 819-0395, Japan \\ 3) SO Pharmaceutical Corporation, 1-5-2 Minatojima minamimachi, Kobe 650-0047, Japan \\ 4) Center for Future Chemistry, Kyushu University, 744 Moto-oka, Fukukoka 819-0395, Japan
}

In this article, we report a novel oil gel sheet, which is contained ascorbic acid and hyaluronic acid as an ingredient of cosmetics. An efficient permeation method of the ingredients into a deep skin would be a key technology to develop novel functional cosmetics. The outer surface of the skin that is stratum corneum has a strong barrier to avoid the invasion of hazardous materials into our body. The barrier function causes the difficulty in the transport of effective ingredients into a deep region of our skin. To overcome this problem, solid-in-oil (S/O) nano dispersion technique has been developed by coating the ingredients with hydrophobic surfactant molecules. The coated hyaluronic acid was well dispersed in an oil phase and its permeation rate into the skin was significantly enhanced by the formation of the complex. An oil gel sheet was created by utilizing the S/O techniques for ascorbic acid and hyaluronic acid. The oil gel sheet could improve the moisture condition of faces by using at least 30 minutes.

Key words : solid-in-oil dispersion / oil gel sheets / hyaluronic acid / drug delivery system

\section{1.はじめに}

化粧品には様々な形態が考えられるが，基本的に は肌に有効な成分を肌の奥深くまで浸透させる技術 が重要となる。一方で，人には外的から身を守る防 御機能が備わっており，その中心的な役割を果たす のが，肌の最外層に存在する角層である．つまり人

* Corresponding Author

Tel: 096-272-0961

Fax: 096-273-4865

E-mail: a-funatsu@libatape.co.jp
間は, この角層の存在によって, 危険な化学物質が 体内に侵入するのを防いでいるのである．しかしな がら，この機能は，有効な化粧品成分を肌の奥深く まで届ける場合には最大の障壁になる，例えば，水 に溶かした成分をそのまま皮膚に塗布した場合には, 分子量 500 以上の物質は浸透しないことが知られてい る.このため化粧品会社では, 肌の奥深くに有効成 分を浸透させるための様々な技術開発が行われて いる.

私たちは，皮膚の角層が疎水的であることに注目 し, 油状基剤に有効成分を可溶化すると肌の奥深く まで浸透させ得ることを見いだした ${ }^{1 \sim 7)}$. しかしな 


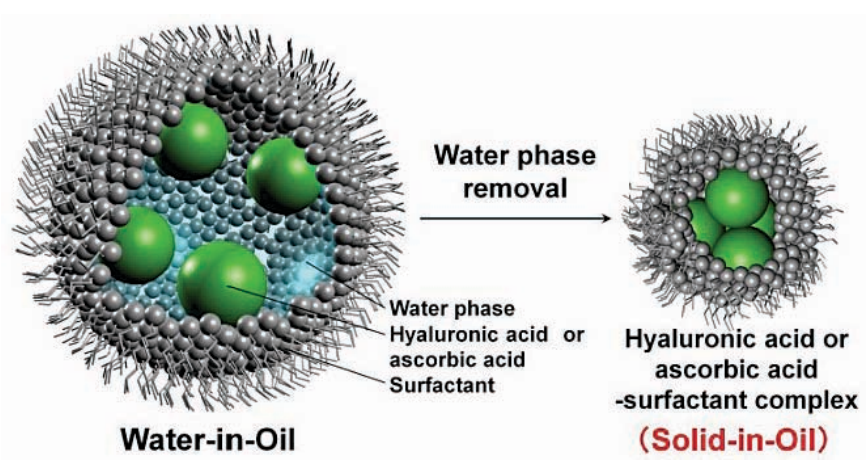

Fig. 1 Schematic illustration of solid-in-oil compared with water-in-oil.

がら，一般に化粧品の有効成分は，水によく溶ける 親水性の場合が多く，油に水溶性の有効成分を可溶 化する手法の開発が不可欠である。この手法が今回 紹介する Solid-in-Oil（S/O）製剤技術であり，有効 成分を界面活性剂の分子膜でナノコーティングする ことによって達成される ${ }^{114}$ ），一方で，有効成分を 長期間持続的に徐放するには，いわゆる今回の主題 である貼る技術，すなわちシート化が必要となる. その意味では, リバテープ製薬は, 絆創亳を日本で 初めて開発した会社であり, 今回の徐放性シートの 開発には最大のパートナーであった。

筆者らは，リバテープ製薬のテープ製剂技術と， 九州大学の Solid-in-Oil (S/O) 製剂技術の融合を試 みた。本特集では前半でヒアルロン酸を例にとり, $\mathrm{S} / \mathrm{O}$ 製剂技術を用いた経皮デリバリーについて解説 し, 後半でリバテープ製薬が開発したオイルゲル シートの特性について紹介する.

\section{2. $\mathrm{S} / \mathrm{O}$ 製剤技術とは}

九州大学ではWater-in-Oil (W/O) エマルション を利用して親水性成分の表面に疎水性界面活性剂を コーティングし, 親水性成分を油状基剤中にナノサ イズで分散させることができる，Solid-in-Oil (S/O) 製剤技術を開発した。 S/O の概念図を Fig. 1に示す.

S/O とは, W/O エマルションから内水相を除去し, 界面活性剂で被覆された状態の親水性成分を再び油 中に分散したものである. W/Oエマルションやマイ クロエマルション等の親水性成分を油状基剂中に分 散させる他の技術と比較したときの $\mathrm{S} / \mathrm{O}$ 製剂技術の メリットには，(1)内水相が存在しないため，W/O工 マルションよりも小さな粒子として油状基剈中に親 水性成分を分散させることができる，(2)凍結乾燥に よって得られた固体である複合体に油状基剤を加え るため, 最終濃度の調整が容易である, (3)他の手法

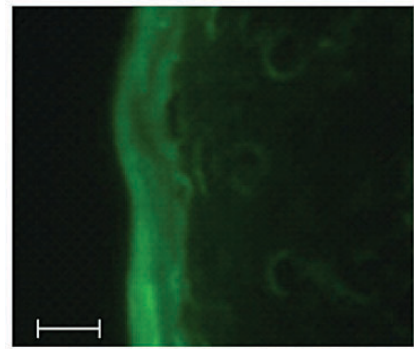

Aqueous solution

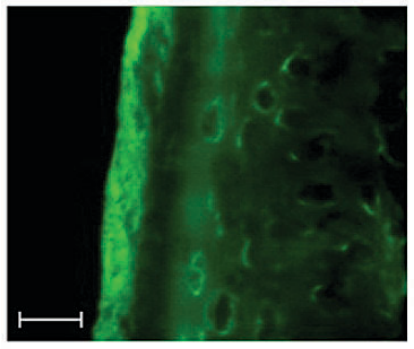

S/O nanodispersion
Fig. 2 Fluorescent microscopy of skin sections treated with aqueous solution and S/O nanodispersion containing ascorbic acid stained by fluorexon (scale bar: 10 $\mu \mathrm{m})$.

よりも親水性成分を高濃度かつ安定に油状基剤中に 分散させることができる等が挙げられる. S/O製剤 技術の特徴は, もともと油には溶けない親水性成分 を油中に分散できる点にある．例えば，ヒアルロン 酸などの親水性高分子を油状基剤中に高濃度で分散 でき, 透明な液体を得ることができる手法は他に存 在しない. W/Oエマルションやマイクロエマルショ ンの場合, どうしても内水相に親水性成分が存在す るために全体としての濃度の低下は避けられず, 高 濃度の場合に粒子径も小さなものは得られない。し かしながら, 親水性の高分子化合物に $\mathrm{S} / \mathrm{O}$ 製剂技術 を施すと，かなり高濃度の透明な液体を得ることも 可能である. さらに1ケ月以上の期間, 沈殿も生じず に安定である点や, 界面活性剂には, 医薬品添加物 として認められているショ糖脂肪酸エステルが利用 できるということが明らかとなっており，本系をそ のまま製剤として利用することが可能である点も大 変魅力である.

\section{3. 経皮デリバリーへの応用}

\section{1 経皮デリバリーについて}

塗り薬のように皮膚を通して体内に物質を送達す る技術は, 経皮デリバリーと呼ばれる. 経皮デリバ リーには非浸襲性や利用の簡便性など極めて重要な メリットが存在する一方で, 一般的に親水性高分子 の経皮デリバリーは非常に難しく, 分子量 500 以上の 物質は皮膚へ浸透できないことが知られている ${ }^{15,16) .}$ その最大の要因は, 表皮最外層の角層によるバリア 機能である. 角層は死細胞から成る疎水性の高い多 層膜で, 外因性物質の皮膚浸透において最も高いバ リア能を示す。したがって親水性高分子の経皮デリ バリーは非常に難しいことが知られている. 


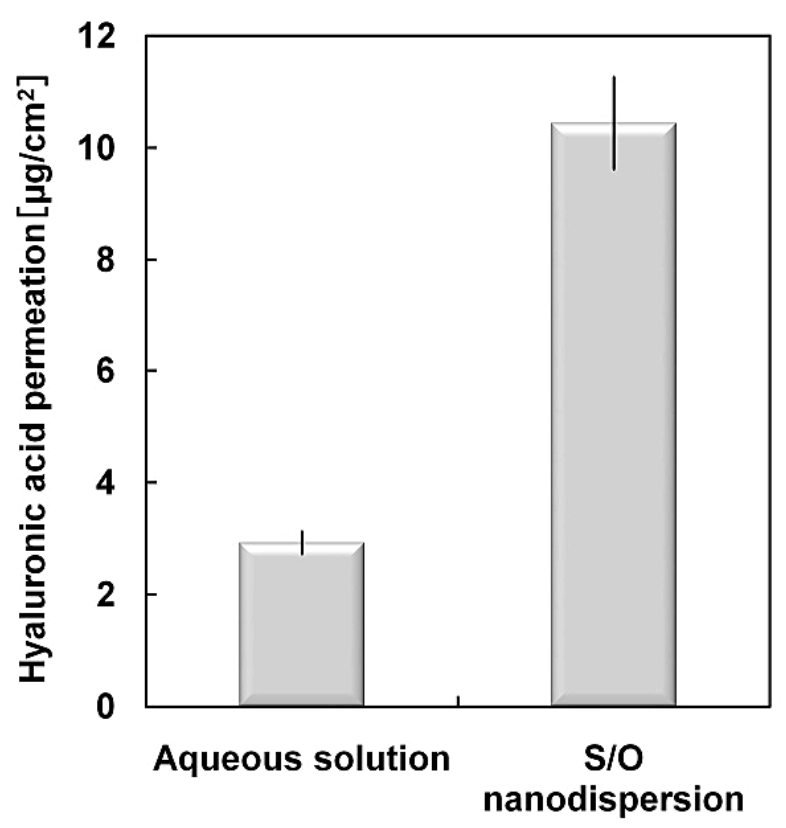

Fig. 3 Hyaluronic acid concentration in the extract, which penetrated into the skin using aqueous solution and $\mathrm{S} / \mathrm{O}$ nanodispersion.

\section{$3.2 \mathrm{~S} / 0$ 製剤技術の経皮デリバリー}

そこで筆者らは上述の $\mathrm{S} / \mathrm{O}$ 製剂技術を利用して， 過去の研究で, アスコルビン酸（ビタミンC）の経 皮デリバリーに成功した（Fig. 2) ${ }^{4)}$.

親水性高分子であるヒアルロン酸を油中に分散さ せ，以下のように経皮デリバリーに挑戦した。蛍光 ラベル化ヒアルロン酸（平均分子量 6,000）の水溶液 とショ糖エルカ酸エステルのシクロヘキサン溶液を 混合し W/Oエマルションを得た。これを直ちに凍結 乾燥し，ヒアルロン酸と界面活性剤からなる固体を 得た. その後ヒアルロン酸の濃度が $0.1 \mathrm{wt} \%$ となる ように，上記固体をミリスチン酸イソプロピル （IPM）に分散し，S/O製剂を調製した。経皮デリバ リー実験では，Yucatan micropig（YMP） スキンの背 部を用い, $\mathrm{S} / \mathrm{O}$ 製剂と水溶液の浸透性の比較を行っ た. 浸透性の評価は, 経皮透過実験後のYMPスキン から皮膚中のヒアルロン酸を抽出し, YMP スキンに 浸透したヒアルロン酸の濃度を測定した。また, YMP スキンの切片を作製し, 蛍光顕微鏡観察も行っ た. Fig. 3 に経皮透過実験後に皮膚中に存在したヒア ルロン酸を定量した結果を示す.Fig 3 より, 今回調 製した $\mathrm{S} / \mathrm{O}$ 製剂を用いると，ヒアルロン酸の水溶液 に比べて約 3.6 倍のヒアルロン酸が透過したことがわ かる．これは皮膚の最外層である角層が疎水性の組 織であるため, 水溶液では表皮へヒアルロン酸を輸 送することが難しいためであると考えられる。一方 で，S/O製剤は，ヒアルロン酸が油状基剤に分散し

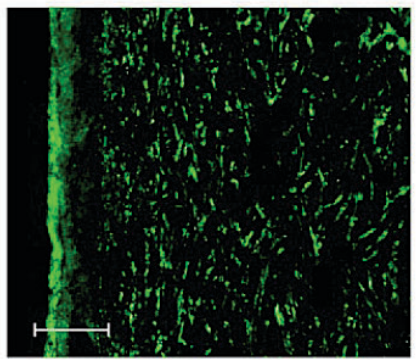

Aqueous solution

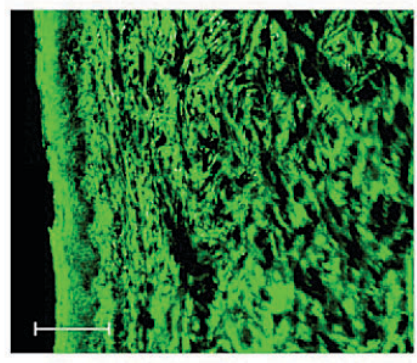

S/O nanodispersion
Fig. 4 Fluorescent microscopy of skin sections treated with aqueous solution and S/O nanodispersion containing fluorescein isothiocyanate labeled hyaluronic acid (scale bar: $100 \mu \mathrm{m}$ ).

ているため, 疎水性である角層を容易に通過するこ とができ, ヒアルロン酸を表皮および真皮中へ輸送 する能力が高くなったと考えられる. また蛍光ラべ ル化したヒアルロン酸の $\mathrm{S} / \mathrm{O}$ 製剤と水溶液を皮膚に 浸透させ，蛍光顕微鏡で皮膚の断面を観察した結果， $\mathrm{S} / \mathrm{O}$ 製剂では表皮全体に強い蛍光が見られ, 皮膚中 にヒアルロン酸が十分浸透していることが確認でき た（Fig. 4). 一方, 水溶液の場合では, 角層部分の 蛍光は見られたが, それ以外の組織では蛍光が非常 に弱いことから, 皮膚深部のヒアルロン酸の透過量 は非常に少ないことが示された。

以上の結果から, 親水性高分子であるヒアルロン 酸は, 水溶液では皮膚浸透性が低いが，S/O製剤技 術によって油状基剤に分散させると, 皮膚中への浸 透が促進されるということが示唆された.

\section{$3.3 \mathrm{~S} / \mathrm{O}$ 製剂の効果の検証}

経皮デリバリーに成功した $\mathrm{S} / \mathrm{O}$ 製剤を用い，その 効果の検証を実施した。この検証には, 今回の検討 により作製したヒアルロン酸の S/O 製剂を用いた。 さらに, この効果の確認方法として, 皮膚の角層水 分量を測定した。最初に被験者は, 両手の甲をよく 洗浄した. 30 分間安静後, 水分計 (コルネオメータ 一CM825 \{ドイツ Courage + Khazaka社\}）を用いて, 角層水分量を測定し, 塗布前の角層水分量とした。 次に， S/O製剤 $0.5 \mathrm{ml}$ 左手によく伸ばしながら塗 布した. 30 分間放置後, コットンで余剰オイルを吸 い取り, 塗布前と同一測定点の角層水分量を測定し た。使用前後の角層水分量の比を用いて評価した。 同時に, 同濃度のヒアルロン酸を水溶液に溶解させ たサンプルを用いてコントロール実験を行い, 被験 者の右手の甲に塗付した. 実験期間は, 一力月間と し，一週間毎に同じ場所に同じ試料を塗布し，その 


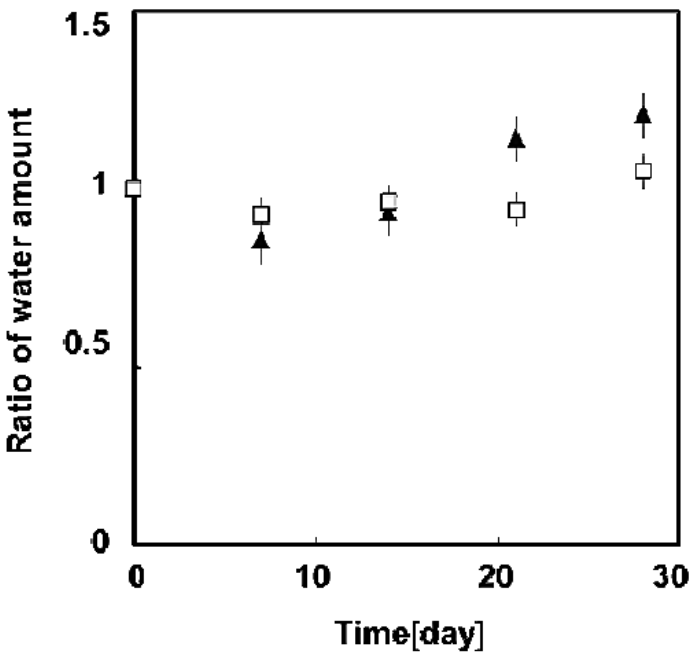

Fig. 5 Ratio of water amount, which saturated using aqueous solution $(\square)$ and S/O nanodispersion $(\mathbf{A})$.

都度左右の手の角層水分量を測定した。その結果を Fig. 5 に示す.

図中，角層水分量比が大きいほど，角質水分保持 能が高いことを示している．この効果の検証実験か らも，S/O製剤技術を使用した場合の角層表面の水 分量が，水溶液を塗布した場合よりも， 1.2 倍以上も 増加していることが確認でき， S/O 製剤化によりヒ アルロン酸が皮膚中へ多く浸透した効果を確認で きた.

\section{S/O 製剂技術利用オイルゲルシート}

\section{$4.1 \mathrm{~S} / \mathrm{O}$ 製剤の経皮デリバリー性能向上に向けて}

$\mathrm{S} / \mathrm{O}$ 製剤の経皮デリバリーをさらに促進させる要 因として，基材種や諸条件等多数があげられる。こ れまでに $\mathrm{S} / \mathrm{O}$ 製剤は，長い時間皮膚と接触させるこ とにより，より皮膚深部へ親水性成分が浸透するこ とを，すでに報告している ${ }^{1,6)}$ 。そのため， $\mathrm{S} / \mathrm{O}$ 製剤 を皮膚表面に長時間接触できる状態を作ることを目 標とし検討を開始した。

\section{2 剂形の検討 1}

長時間 $\mathrm{S} / \mathrm{O}$ 製剂を皮膚表面に維持させるために， まずその形態に着目した。一般に，製剤の剂形の代 表として，塗り薬のような「塗る」剤形，とテープ 製剂のような「貼る」剂形があげられる，両者の諸 特性の比較は，しばしば報告され $\left.{ }^{17}, 18\right)$ ，一般的に 「塗る」剂形が初期経皮デリバリー性能に優れ，「貼 る」剂形が持続性経皮デリバリー性能に優れている といわれる。そこで，剂形の違いによる $\mathrm{S} / \mathrm{O}$ 製剤の 経皮デリバリーの性能比較を行った。今回も，ヒア

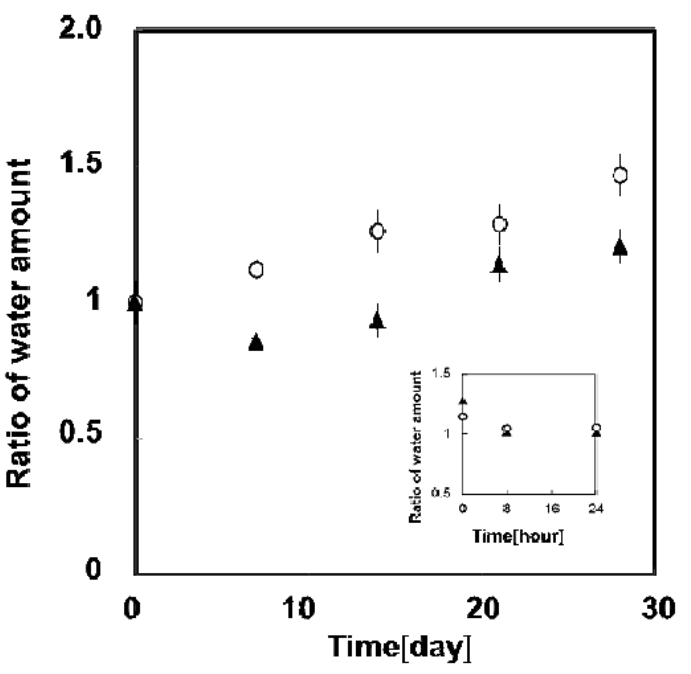

Fig. 6 Ratio of water amount, which saturated using S/O nanodispersion $(\mathbf{A})$ and S/O Oil Sheets $(\bigcirc)$. The inset shows ratio of water amount for 1 day.
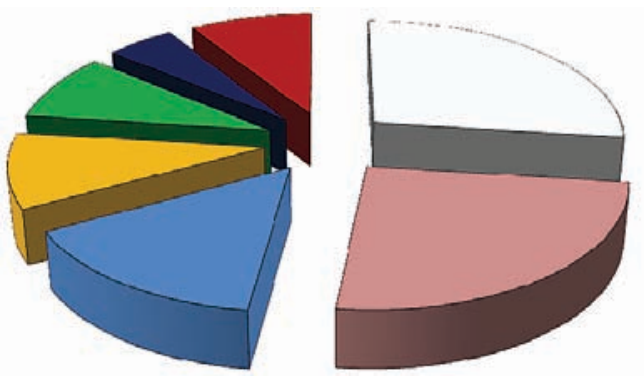

口不快婜

口压迫感

ロ粘着カが強い

ロ剥がれる

ロ瘈い・かふれる

・良い

घその他

Fig. 7 Result of the questionnaire of image to tape.

ルロン酸の $\mathrm{S} / \mathrm{O}$ 製剂を用い，この効果の確認として， 皮膚の角層水分量（使用前・後）を測定した。今回 のサンプルの「塗る」剤形には $\mathrm{S} / \mathrm{O}$ 製剂を，「貼る」 剂形には，S/O製剤 $0.5 \mathrm{ml}$ を浸み込ませたパッドを テープで固定したサンプルを用いた。これを先程と 同様に水分量を測定した。その結果を Fig. 6に示す.

この結果より，「塗る」剤形は，伸び易いため，皮 膚の広い範囲の凹凸の隅々まで行き渡りやすい。そ のため, 予想通り初期の経皮デリバリー性能（Fig. 6 中）は，「塗る」剤形の方が優れ，「貼る」骺形では 長期間にわたる角質水分保持能力が高く持続性があ ることが確認できた，以上の検討結果より，S/O製 剂を長時間皮膚表面と接触でき経皮デリバリー性能 を向上できる形態は，「貼る」剤形であることが確認 できた.

\section{3 剂形の検討(2)}

長時間皮膚表面と接触できる「貼る」剤形の代表 として, 各種テープ製剤や発布剤があげられる。そ こで，このような $\mathrm{S} / \mathrm{O}$ 製剤の「貼る」剤形について, 


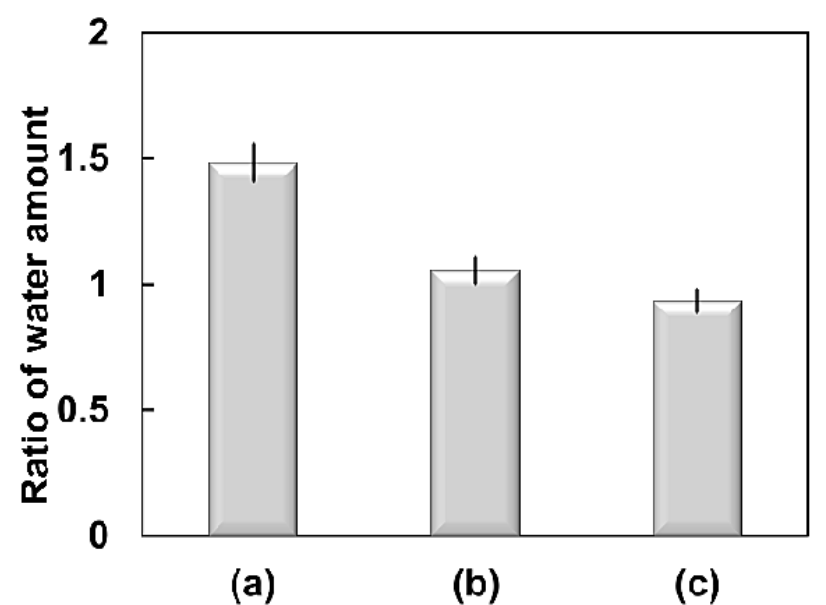

Fig. 8 Ratio of water amount, which saturated using

(a) Base-material less,

(b) Non-woven PP material (thickness: $285 \mu \mathrm{m}$ ),

(c) PP film (thickness : $140 \mu \mathrm{m}$ ) (PP: polypropylene).

外的要因 (外観・イメージ) の情報取集と, 内的要 因（効果の確認）による実験を行った. まず外的要 因の情報収集の 1 つして，一般的な「貼る製剤」の イメージについてのアンケートを行った．この結果 を Fig. 7 に示す.

ここに示すように，貼ることにより粘着性由来の 不快感や圧迫感があるため長時間貼るのは困難であ り，見た目においても不快感があるといった欠点が あることが確認できた。 次に内的要因調査として, 貼ることによる皮膚との接触方法やその効果につい て検討した。皮膚表面に製剤をよりよく貼り付ける ためには，皮膚表面の凹凸（表面形状），「ぬれ性」 「摩擦特性」, 皮膚表面硬度による「表面弾性」とい った特性に着目する必要がある。今回は，この中で も肌の表面凹凸と弾性に注目し，S/O「貼付」製剂 の効果を確認した。皮膚表面には, 皮溝とよばれる 種々の深さ，長さの溝が走行している．その深さ大 きさは, 数 $100 \mu \mathrm{m}$ 程度といわれており ${ }^{19)}$, より効果 的に製剂を肌へぬれさせるためには，この山凸に追 従しかつヒトの皮膚の表面弾性よりも柔らかいもの が必要となる。そのため検証用サンプルの粘着層に は, 皮膚表面弾性より低い状態に設計するため, 才 イルゲル化したものを利用した. 出来上がりのオイ ルゲルの表面硬度は，ヒトの皮膚表面硬度 ${ }^{20)} よ り$ 低 い値となるように制御した，さらに，肌に追随しゃ すくゴムのように伸縮できるような弾性を維持させ た。このような粘着剤を一般的なテープ製剤やパッ プ材に使用される不織布やプラスチックフィルムに 塗り，サンプルを作製した．今回は，このような基 材があるサンプルと, 基材が全く無いものを含めた 3
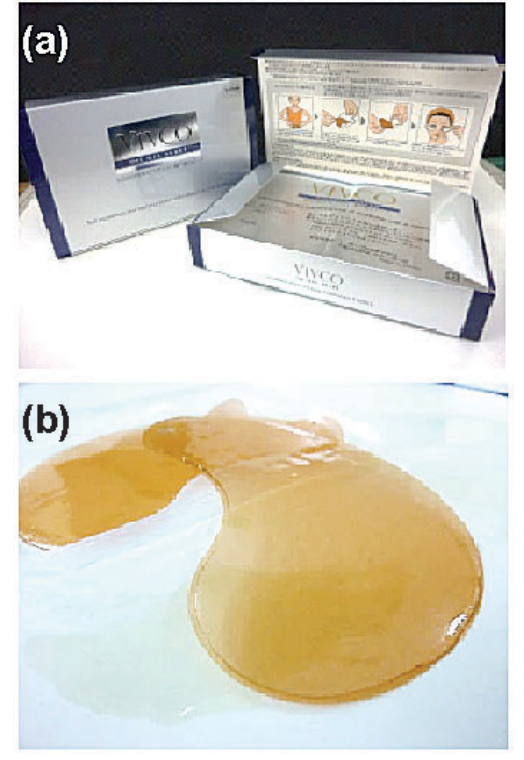

Fig. 9 Oil gel sheets utilizing solid-in-oil technique

(a) Photograph of product externals,

(b) Photograph of product contents.

種類を準備した.このときの角層水分量測定結果を Fig. 8へ示した. これより基材有サンプルよりも, 基 材無のサンプルの方が，角層水分量が高いことが明 らかとなった。 さらに，これらのサンプル間の皮膚 表面へのぬれ方と接着性を検討した。 まず，基材有 サンプル 2 種ともに, 基材側に粘着剂層（オイルゲル） がひっぱられ, 皮膚の凹凸に接触していない点があ ることがわかった. それに対し, 基材無サンプルで は, 何の制御も無いため, 皮丘に沿うように粘着層 が落とし込まれ, 隅々までいきわたるように皮膚表 面にぬれる傾向にあることがわかった，基材無サン プルは, このような状態で皮膚にぬれるため, 粘着 層と皮膚の表面の接触面積が増え, より有効成分が 浸透しやすい状態になり, 角層水分量が高くなった と推察した。

\section{S/O製剂技術利用オイルゲルシート化粧品}

これまで報告してきたような知見を活かし，親水 性成分を皮膚深部への浸透を促進する $\mathrm{S} / \mathrm{O}$ 製剤技術 を最大限に引き出すべく開発した製品が Fig. 9 の 「VIVCOオイルゲルシート」である. これは, 株式会 社ココカラファインと九州大学, リバテープ製薬株 式会社がそれぞれの専門分野で協力し, 共同開発し 生まれた製品である。この製品は，ここで紹介した ような親水性有効成分（「ビタミンC」「ヒアルロン 酸」）の皮膚深部への浸透が確認でき, その効果が期 
待される製品である.

\section{6. 結 語}

今回親水性高分子であるヒアルロン酸の $\mathrm{S} / \mathrm{O}$ 製剂 化に成功し, ヒアルロン酸が皮膚深部まで浸透され ていることが確認できた。 この S/O 製凨技術の経皮 デリバリー性を最大限に引き出せる剤形が，「貼る」 凨形であることが今回の実験より確認できた。この 「貼る」剂形を用いることにより，手軽に肌の奥深く まで有効成分を浸透させることが実証された。さら に，この知見を基に開発された製品が「オイルゲル シート」である。今後も，これらのような $\mathrm{S} / \mathrm{O}$ 製剂 技術を利用した製品が多数生み出されることを期待 したい.

\section{文献}

1) Tahara $Y$, Honda $S$, Kamiya N, Piao H, Hirata A, Hayakawa E, Fujii T, Goto M : J. Control. Release, 131, 14 (2008)

2) 後藤雅宏, 早川栄治, 平田彰彦, 山下 健, 水野恒政, 河原清章，柳 裕啓 : 膜 (Membrane), 34, 159 (2009)

3) 田原義朗, 神谷典穂, 後藤雅宏 : バイオサイエンスと インダストリー (トピックス), 67,68 (2009)

4) 大熊愛子, 朴 洪宇, 田原義朗, 神谷典穂, 後藤雅宏 : 膜 (Membrane)，34, 227 (2009)

5) 田原義朗, 神谷典穂, 後藤雅宏 : PHARM TECH JAPAN, 25, 1409 (2009)

6) Tahara $Y$, Namatsu K, Kamiya N, Hagimori M, Kamiya S, Arakawa M, Goto M : Chem. Comm., 46, 9200 (2010)

7) 後藤雅宏: ファインケミカル, 39, 49 (2010)

8) Toorisaka E, Ono H, Arimori K, Kamiya N, Goto M : Int. J. Pharm., 252, 271 (2003)

9) Piao H, Kamiya N, Watanabe J, Yokoyama H, Hirata A, Fujii T, Shimizu I, Ito S, Goto M : Int. J. Pharm., 313159 (2006)

10) 後藤雅宏 : ファルマシア, 42823 (2006)

11) Piao H, Kamiya N, Hirata A, Yokoyama H, Fujii T, Shimizu I, Ito S, Goto M : Pharm. Dev. Technol., 12, 321 (2007)

12) Yoshiura H, Hashida M, Kamiya N, Goto M : Int. J. Pharm., 338, 174 (2007)

13) Piao H, Kamiya N, Hirata A, Fujii T, Goto M : Pharm. Res., 25, 896 (2008)

14) Yoshiura H, Tahara Y, Hashida M, Kamiya N, Hirata A, Fujii T, Goto M : Biochem. Eng. J., 41, 106 (2008)

15) Thomas BJ, Finnin BC : Drug Discov. Today, 9, 697 (2004)

16) Bos JD, Meinardi MMHM : Exp. Dermatol., 9, 165 (2000)

17）権 英淑，神山文男，山本 昌：Fragrance Journal, 34, $52(2006)$
18）権 英淑 : COSMETIC STAGE, 4, 23 (2010)

19) 白土寬和, 野々村美宗, 前野隆司 : 日本機械学会論文 集（C編），73,541 (2007)

20) Kuwahara Y, Shima Y, Shirayama D, Kawai M, Hagihara K, Hirano T, Arimitsu J, Ogata A, Tanaka T, Kawase I : Rheumatology, 47, 1018 (2008)

(Received 27 December 2010; Accepted 8 January 2011)

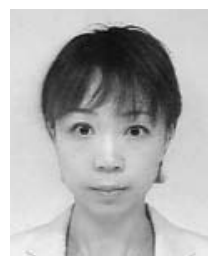

\begin{tabular}{|c|c|}
\hline \multicolumn{2}{|l|}{ 著者略歴 } \\
\hline 船津 麻美 & ふなつ あさみ） \\
\hline 2002年 3 月 & 熊本大学大学院自然 \\
\hline & $\begin{array}{l}\text { 科学研究科博士前期 } \\
\text { 課程修了 }\end{array}$ \\
\hline 2002年 4 月 & 日東電工株式会社 \\
\hline & 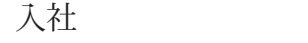 \\
\hline 2009年 9 月 & リバテープ製薬株式 \\
\hline & 会社入社 \\
\hline 009年 & 熊本大学 \\
\hline & $\begin{array}{l}\text { 科学研学 } \\
\text { 課程入学 }\end{array}$ \\
\hline
\end{tabular}

現在に至る

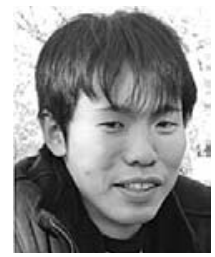

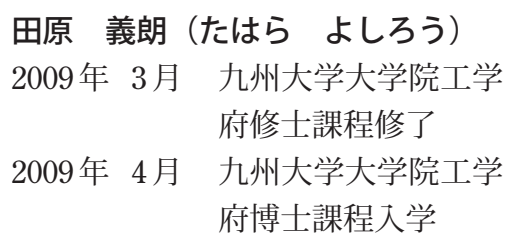

現在に至る

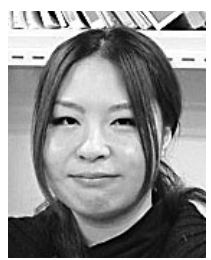

山中 桜子（やまなか さくらこ） 2009年 6 月 ASPION 株式会社 (現SOファーマ株式 会社）入社

現在に至る

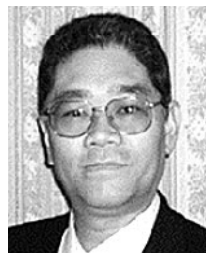

後藤 雅宏（ごとう まさひろ）

1989年 3月 九州大学大学院工学 研究科博士課程修了

1990年 6 月 九州大学工学部 助 教授

1994年 6月 MIT化学工学科 客 員教授

2001年 11月 九州大学工学研究院 教授

2008年 4月 九州大学末来化学創 造センター長

現在に至る 